\title{
Chemical composition of groundwater in the zone of slow water exchange of the Upper Pontian aquifer, Northwestern Bulgaria
}

\author{
Aglaida Toteva ${ }^{l}$, Stefan Shanov
}

${ }^{1}$ Geological Institute, Bulgarian Academy of Sciences, 1113, Sofia, Bulgaria;

e-mail: aglaya.j@abv.bg; s_shanov@abv.bg

\section{Формиране на химичния сьстав на подземните}

води в зоната на забавен водообмен на

Горнопонтийския водоносен хоризонт,

Северозападна България

\author{
Аглаида Тотева, Стефан Шанов
}

Toteva, A., S. Shanov. 2021. Chemical composition of groundwater in the zone of slow water exchange of the Upper Pontian aquifer, Northwestern Bulgaria. Engineering Geology and Hydrogeology, 35, $23-30$.

\begin{abstract}
The Upper Pontian aquifer occupies the central part of the Lom Depression. The geological position determines its gradual dipping from the periphery to the central parts. It is one of the most water-abundant aquifers in Northwestern Bulgaria and is associated with the sands of the Archar Formation. The chemical composition of the waters is of interest and is important for the water supply in the area. The analysis of the data shows that there are regularities in the change of the water quality with aquifer depth. Significant differences in some of the hydrochemical parameters are found in the zone of slow water exchange and geological and hydrogeological explanations have been sought.
\end{abstract}

Keywords: groundwater, hydrochemistry, Lom Depression, Northwestern Bulgaria.

Резюме. Горнопонтийският водоносен хоризонт заема централната част на Ломската депресия. Неговото геоложко положение определя постепенното му затъване от периферията към централните части. Той е един от най-водообилните водоносни хоризонти в Северозападна България и е вместен в пясъците на Арчарската свита. Химичният състав на водите представлява интерес и е от значение за водоснабдяването в района. Анализът на данните показва, че съществуват закономерности в промяната на качествата на водите със затъване на водоносния хоризонт в дълбочина. В зоната на забавения водообмен се установяват значителни разлики в някои от хидрохимичните показатели и са потьрсени геоложки и хидрогеоложки причини за това. В района на Цибърската низина няма съществено затъване на водоносния хоризонт, но има промяна на химичен състав и минерализация. Предполага се, че е възможен приток на по-високо минерализирани води от дълбочина.

Ключови думи: подземни води, хидрохимия, Ломска депресия, Северозападна България. 


\section{Introduction}

The chemical composition of groundwater is important, both for the assessment of the ecological condition and for the safety of its use by humans. The main factors for the formation of the chemical composition are the hydrogeological conditions and the processes of water-rock interaction. The aim of the present study is to determine the factors contributing to the presence of anomalous values in the study area within one of the most important aquifers in Northwestern Bulgaria - the Upper Pontian. Particular attention is paid to the waters located in the area with relatively slow water exchange, located far from the recharge zone. In this area, a zone of an abnormal chemical composition is observed, relative to its neighboring zones.

\section{Object of research}

The Lom artesian basin falls in the Lower Danube artesian region - North Bulgarian artesian basin. It is composed of Neozoic and Upper Cretaceous rocks, which are separated in depth from the Mesozoic aquifers of the Lower Danube artesian region by a regional impermeable layer, designated as "Lower Cretaceous waterproof plate" Iv. Stanev (2014). The Upper Pontian aquifer occupies the central part of the Lom Depression. It comprises clean sands, fine to coarse-grained. It is characterized by high water abundance and coincides with the so-called Archar Formation (Kojumdgieva, Popov, 1988). The predominant thickness of the sand deposits is approximately 40-60 $\mathrm{m}$. The lower waterproof layer is represented by alternating sands and clays, and the upper is covered with clay deposits with sand lenses and interlayers. The geological position - in the range of the Lom Depression, determines the gradual dipping of the aquifer from the periphery to its central parts (Benderev et al., 2010). The groundwater is recharged by infiltration of precipitation in the outcrop areas and groundwater flow from neighboring hydrogeological units. The groundwater discharge occurs in the lowlands along the Danube River. The groundwater flow direction is from south to north-northeast. Several zones can be distinguished within the boundaries of the aquifer distribution (Fig. 1). The first zone is associated with the aquifer outcrops. In this case, the groundwater is recharged directly by precipitation. In the second zone, the recharge takes place indirectly, as the rainwater passes through the loess deposits covering the aquifer. Naturally this leads to lower recharge values. In the third zone, the Upper Pontian aquifer is covered by the alluvial aquifer. Alluvial waters provide indirect recharge of surface waters into the aquifer. The fourth zone is the area where there is a direct discharge into the Archar-Orsoya lowland. In the last zone, the aquifer is covered mainly by low permeable materials overlaying the sand complex. The groundwater regime here changes from unconfined to confined (Benderev et al., 2010).

The Upper Pontian aquifer is generally inhomogeneous in terms of permeability, despite its relative uniformity in terms of thickness. The permeability of sediments is variable and is related to the paleogeographic environment during their deposition. The clayey component in the sediment gradually increases from southwest to northeast, resulting in a decrease in hydraulic conductivity. The area of the Tsibar lowland, which is the subject of the present study, is located in the central part of the aquifer. The Tsibar lowland is one of the Danube lowlands, representing fragments of the alluvial terrace of the Danube River. Each of them is characterized by its specific hydrogeological and hydrochemical features (Gerginov, Krastanov, 2008; Krastanov, Benderev, 2013; Benderev et al., 2014). In this section, the top of the Upper Pontian aquifer is at a depth of approximately $100 \mathrm{~m}$ (Benderev et al., 2010). The isotope studies of Túri et al. (2019) aim at examining the groundwater, which is formed in different climatic conditions and evaluating the residence time of the water in the aquifer (its age). The age determinations by ${ }^{3} \mathrm{H} /{ }^{3} \mathrm{He}$ proved that drilling waters near the village of Dolni Tsibar were between 9600-11600 years old and correspond to a large extent to the 


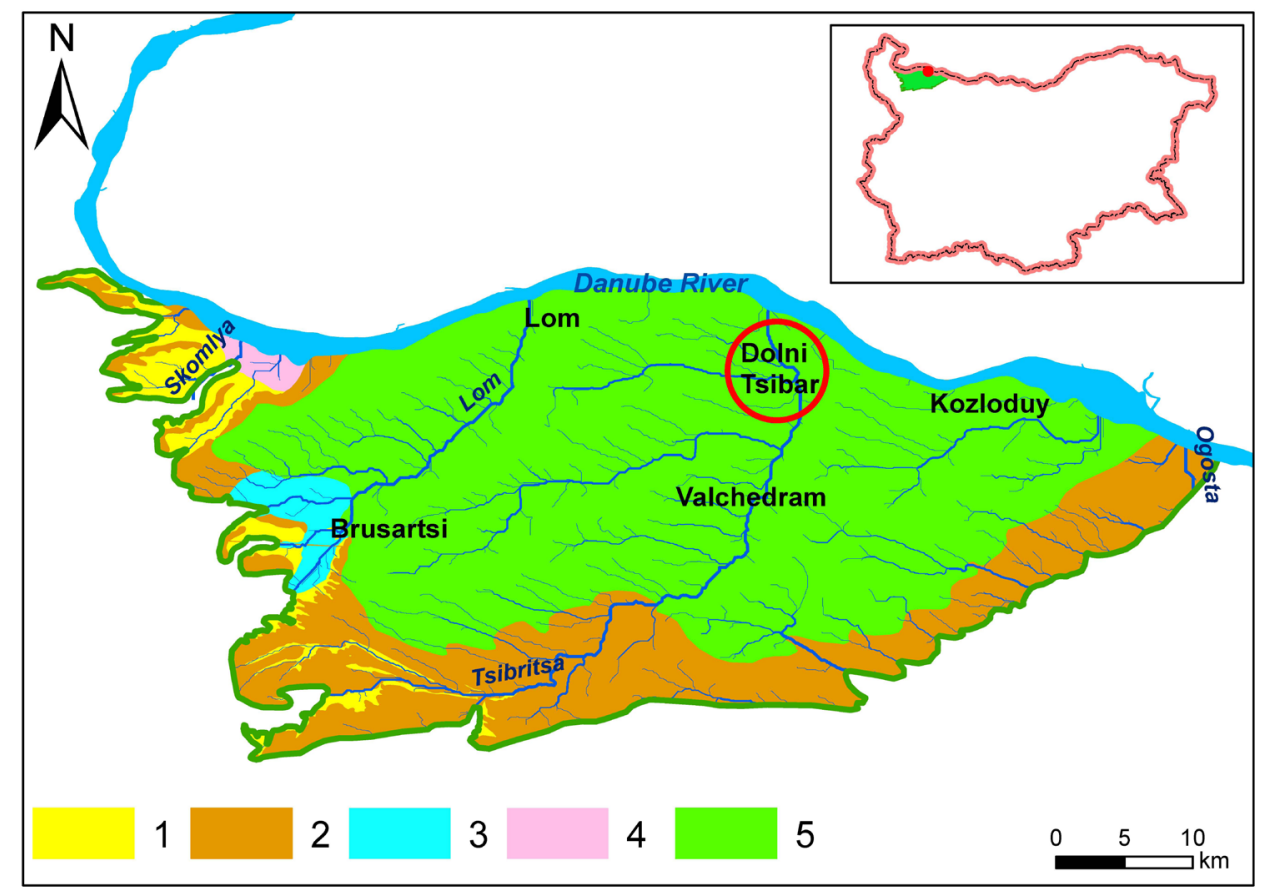

Fig. 1. Boundaries and zones of the Upper Pontian aquifer (Benderev et al., 2010): 1. Aquifer outcrops; 2. Recharge through loess cover; 3. Alluvial recharge; 4. Discharge into the Archaro-Orsoy lowland; 5. Confined zone. Фиг. 1. Граници и зони на Горнопонтийския водоносен хоризонт: 1. зона на разкритие на хоризонта; 2. зона, в която хоризонта е покрит от льосови наслаги; 3. зона на подхранване на водоносния хоризонт от алувиални наслаги; 4. зона на дрениране на водоносния хоризонт в Арчаро-Орсойската низина; 5. зона, в която водоносния хоризонт е покрит от водоупорни материали и водите са напорни.

Late Pleistocene or the transition time between the two periods (Early Holocene - Late Pleistocene). Based on the analysis and comparison of the results, the conclusions can be made as follows. For well TK in Dolni Tsibar lowland it is assumed that the inflow of groundwater occurred during the glacial Holocene transition. The analyses showed low content of radiocarbon and minimal low content of tritium in the samples of the well in the village of Dolni Tsibar, the hypothesis for their recharge related to the transition period is confirmed.

\section{Hydrochemical research}

The hydrochemical analysis of the Upper Pontian aquifer was based on 96 water samples dating from 1974 to 2017. The concentrations and changes of indicators characterizing the chemical composition of groundwater is studied using GIS analysis by the Kriging method. The total dissolved solids (TDS) increases in deeper groundwater in the SW$\mathrm{NE}$ direction and reaches values above $1.5 \mathrm{~g} / \mathrm{L}$ in the area around the village of Dolni Tsibar (Fig. 2). The $\mathrm{Cl}^{-}$values within the layer are in the range up to $0.25 \mathrm{~g} / \mathrm{L}$. The tracing of the chloride ion in the analyzed water samples shows an increase in the deep parts of the aquifer, where the water exchange is significantly slowed down without significant groundwater recharge. In the area around the village of Dolni Tsibar $\mathrm{Cl}^{-}$ concentration values reaches values exceeding $0.50 \mathrm{~g} / \mathrm{L}$ (Fig. 3). In the same area there is an increased content of $\mathrm{NO}_{2}^{-}$, which indicates reduced conditions. In most cases, the waters of the Upper Pontian aquifer are characterized as hydrocarbonate-calciummagnesium-sodium (Fig. 4) with an average TDS content of $0.65 \mathrm{~g} / \mathrm{L}$. In the region of the Tsibar lowland, different types of groundwater are found, and some samples are 


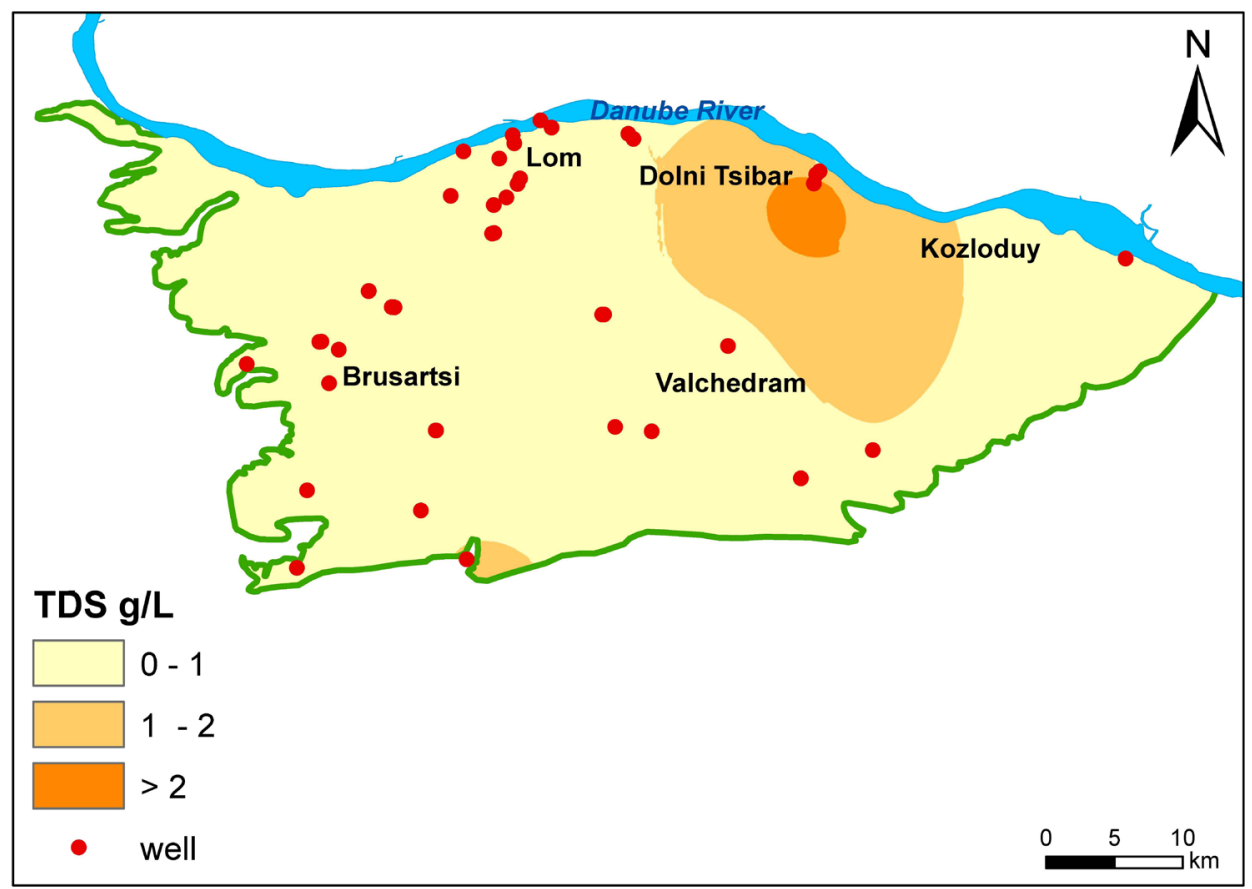

Fig. 2. Chemical composition of groundwater in Upper Pontian aquifer by TDS.

Фиг. 2. Химичен състав на подземните води в Горнопонтийския водоносен хоризонт по обща минерализация (TDS).

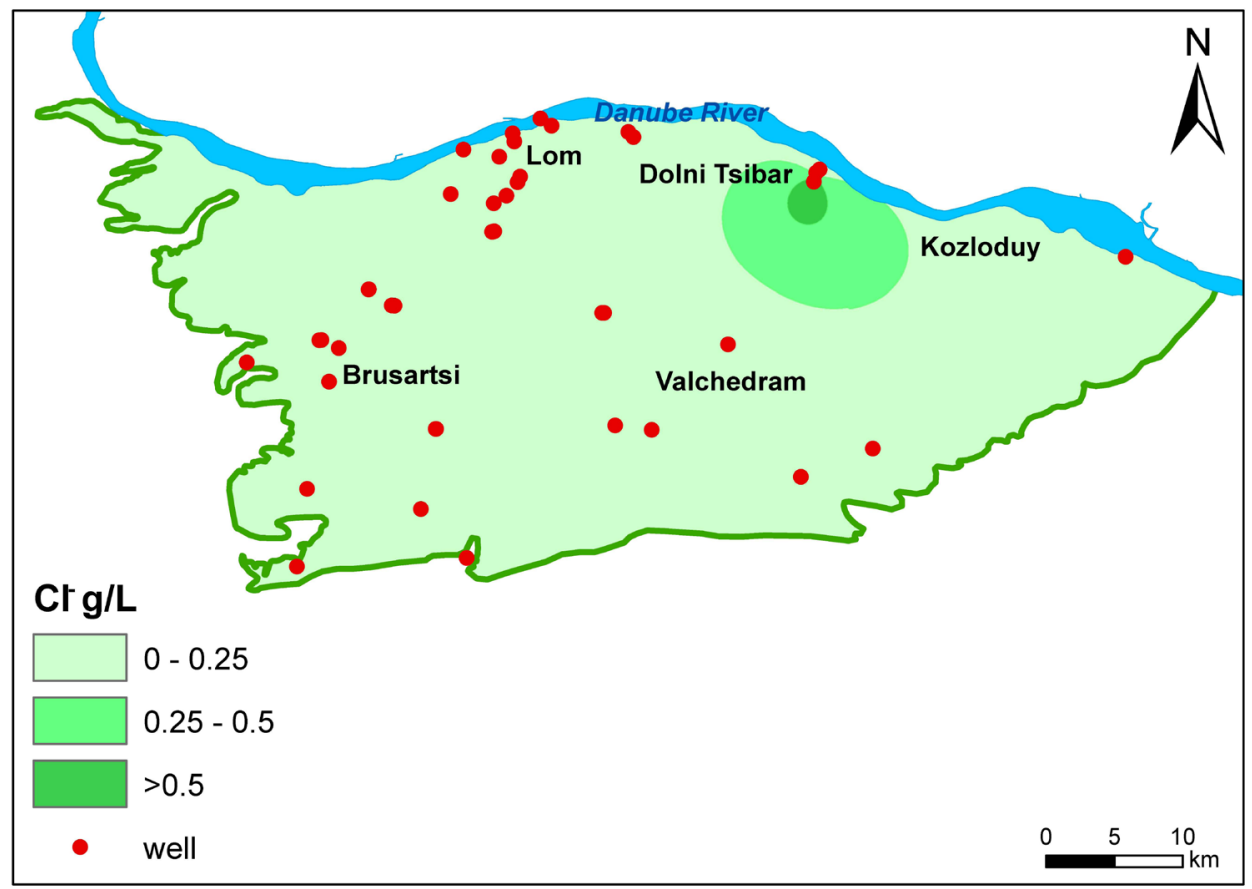

Fig. 3. Chemical composition of groundwater in the Upper Pontian aquifer by $\mathrm{Cl}^{-}$.

Фиг. 3. Химичен състав на подземните води в Горнопонтийския водоносен хоризонт по $\mathrm{Cl}^{-}$. 


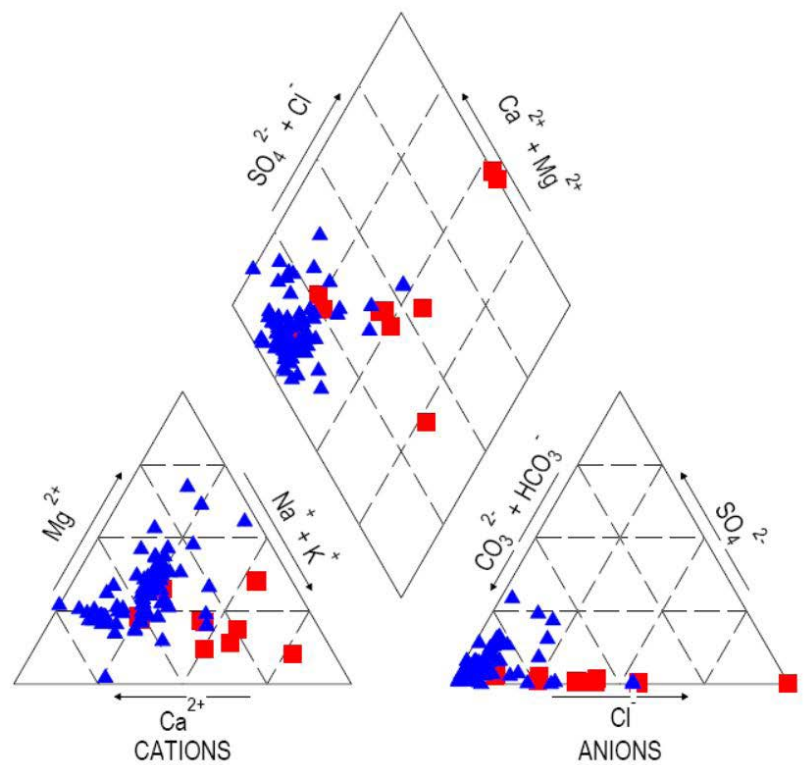

Fig. 4. Piper diagram of the waters of the Upper Pontian aquifer.

Фиг. 4. Пайпер диаграма на химичния състав на водите на Горнопонтийския водоносен хоризонт.

chloride-sodium type. The presence of elevated contents of $\mathrm{Na}$ and $\mathrm{Cl}$ ions implies mixing of groundwater with water from a deeper horizon. The variable values of the quality indicators in the boreholes in the region of the Tsibar lowland are due to their contact with fresh waters and reduced condition.

\section{Discussion}

The established hydrochemical anomaly in the Upper Pontian aquifer in the area of the Tsibar lowland requires to look for an explanation. Based on the established regularities in the change of chemical composition of the groundwater in the Lower Danube artesian basin, it is established that with depth there is a gradual change in composition and an increase in total dissolved solids (Yovchev, Ryzhova, 1962; Trayanova et al., 2019).

As there is no significant dip of the aquifer in the area but in the same time there is a change in chemical composition and TDS content, it can be assumed that there is a possible intensive inflow of mineralized water from depth. To determine whether this hypothesis is plausible, the data on available aquifers in depth and their water quality parameters were analyzed. According to the nearest oil and gas prospecting borehole $3320 \mathrm{~m}$ deep, located about $7 \mathrm{~km}$ west of Dolni Tsibar, it is established that the first aquifer, which is about $700 \mathrm{~m}$ below the Upper Pontian, is the Upper Cretaceous (Maastricht), and at another $1000 \mathrm{~m}$, is the most abundant aquifer in Northern Bulgaria - the Upper Jurassic-Lower Cretaceous. Both aquifers are characterized by stagnant regime and high TDS content. An unclear question is whether there is a possibility of upward flow from the deep aquifers. Based on seismic surveys for oil and gas prospecting and exploration, a deep tectonic fault called the Tsibritsa fault is established. Its orientation coincides with the valley of Tsibritsa river and mainly affects parts of Triassic sediments. This suggests that some authors believe that this fault also affects more recent rocks (Bonchev, 1936; Kotzev et al., 2001), but the question of whether it is active remains controversial. This problem is not significant 
from a hydrogeological point of view - it matters whether there are permeable zones in it, where there is a possibility of vertical inflow of highly mineralized waters. To begin with, a reconfiguration geophysical profile was performed (Fig. 5) using a PQWTTC300 apparatus, which is based on the measurement of natural currents and allows information to be obtained up to a depth of $300 \mathrm{~m}$ below the surface. The profile is 250 meters long and is oriented west-northwest - east - northeast, across the probable spread of Tsibritsa fault. The obtained results show that although the presence of a well-defined layer structure was assumed, vertical inhomogeneity, probable reflection of the fault was observed and water inflow from depth could be assumed.

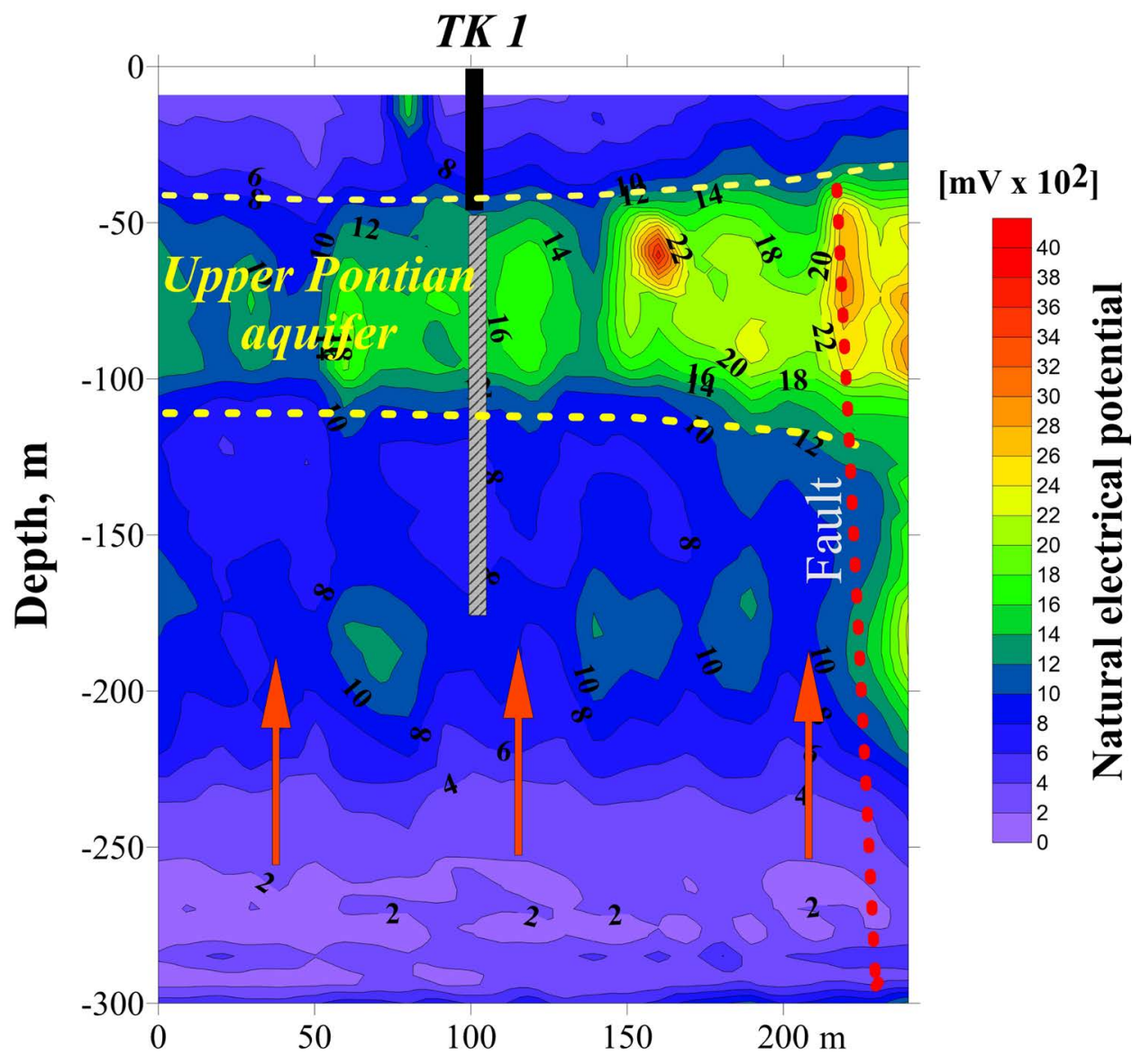

Fig. 5. Geophysical profile in the Tsibar lowland with localization of possible zones for vertical water transport from depth.

Фиг. 5. Геофизичен профил в Цибърската низина с локализация на възможни зони за вертикален пренос на вода от дълбочина.

Of interest is the fact that the type of chemical composition and the contents of some components in the water is not constant over time, with the most variable concentrations being those of chlorine, sodium and total dissolved solids (TDS). This also confirms the possibility of mixing deep waters with the groundwater of the Upper Pontian aquifer depending on momentary changes in the conditions of water recharge and exploitation (Fig. 6). 


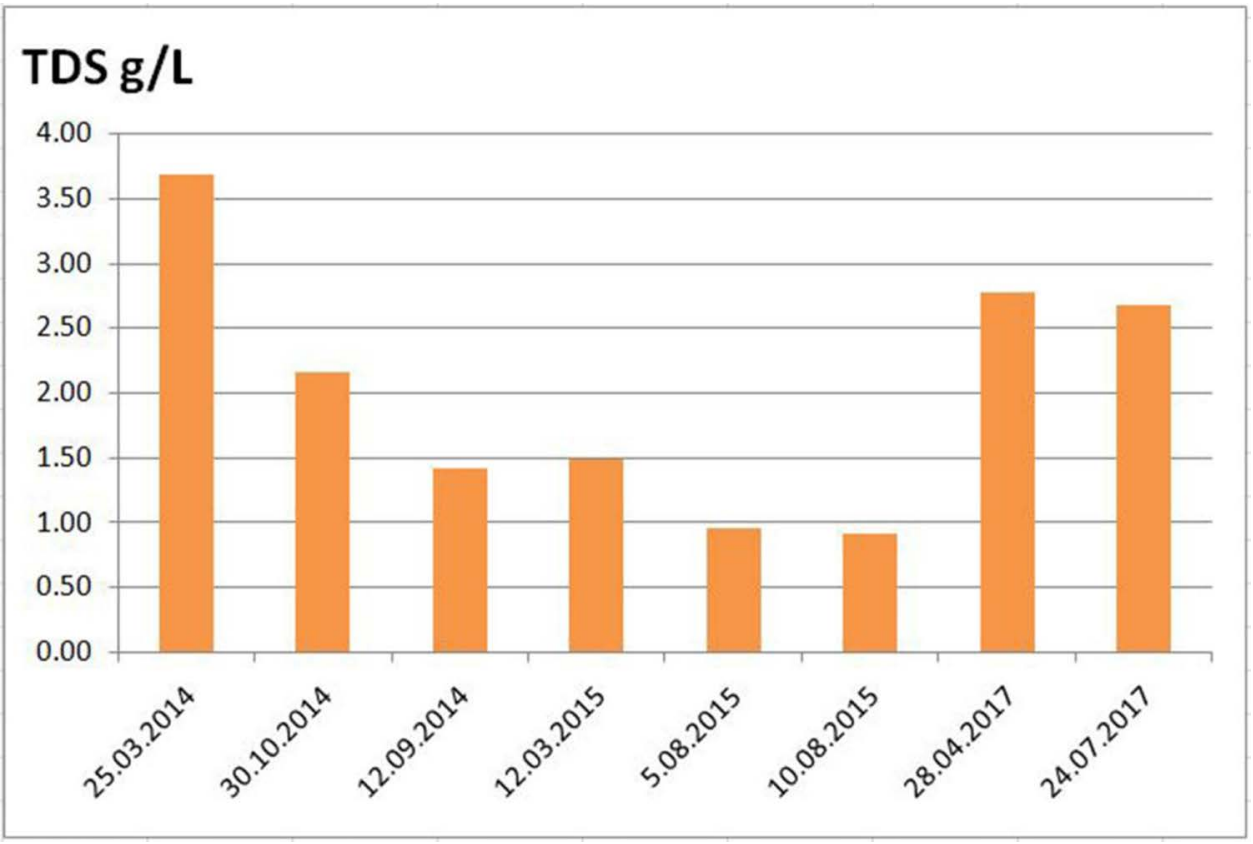

Fig. 6. Modification of TDS in a well TK1 Dolni Tsibar.

Фиг. 6. Промяна на общата минерализация (TDS) в сондаж TK1 Долни Цибър.

\section{Conclusion}

The analysis of the obtained results provides justification for hypothesizing the presence of inflow of higher mineralized sodium chloride waters from deeper aquifers. The degree of mixing depends on the current conditions of water supply and operation in this area. Obviously, additional studies are needed for the final proof of this hypothesis, including geophysical surveys, water level observations over time and, certainly, longterm experimental hydrogeological studies with monitoring of changes in chemical and isotopic composition.

\section{Acknowledgements}

This This work has been carried out in the framework of the National Science Program "Environmental Protection and Reduction of Risks of Adverse Events and Natural Disasters", approved by the Resolution of the Council of Ministers № 577/17.08.2018 and supported by the Ministry of Education and Science (MES) of Bulgaria (Agreement № Д01-363/17.12.2020).

\section{References}

Benderev, A., M. Krastanov, B. Berov. 2014. Assessment of the main factors which influence the vulnerability of groundwater in the Danubian lowlands. Problems of Geography, 1-2, 87-99 (in Bulgarian with English abstract).

Benderev, A., V. Spasov, B. Mihaylova, T. Vasileva. 2010. Hydrogeological settings of the Lom coal basin and problems relevant to the future mining development. Engineering Geology and Hydrogeology, 25, 123-142 (in Bulgarian with English abstract). 
Boncev S. 1936. Geologische Skizze Bulgariens. In: IVth Congress of Slavic Geographers and Ethnographers, Sofia, August 16-29, 1936, 29-40 (in German).

Gerginov, P., M. Krastanov. 2008. Evaluation of the contamination in shallow aquifers caused by industrial activity. Geologica Balcanica, 37, 1-2, 85-90.

Kojumdgieva, E., N. Popov. 1988. Lithostratigraphy of the Neogene deposits in Northwestern Bulgaria. Paleontology, stratigraphy and lithology, 25, 3-26 (in Bulgarian).

Kotzev, V., R. Nakov, B. Burchfiel, R. King, R. Reilinger. 2001. GPS study of active tectonics in Bulgarian: results from 1996 to 1998. Journal of Geodynamics., 31, 2, 189-200, https://doi.org/10.1016/S0264-3707(00)00027-2.

Krastanov, M., A. Benderev. 2013. Hydrochemical regime of groundwater in the Danube lowlands. In: National Conference with International Participation "Geosciences 2013", 119-120 (in Bulgarian with English abstract).

Stanev, Iv. 2014. Deep hydrogeological division of Bulgaria. Review of the Bulgarian Geological Society, 75, 1-3, 5-24 (in Bulgarian with English abstract).

Trayanova, M., S. Kolev, N. Hristov, A. Benderev, N. Sechkaryov. 2019. Hydrochemical characterization of groundwater in Mesozoic aquifers in Central Northern Bulgaria. In: Proc. 19-th International Multidisciplinary Scientific GeoConference SGEM 2019, Vol. 19, 1.2., 2019, 305-312, https://doi.org/10.5593/sgem2019/1.2/ S02.039.

Túri, M., M. Molnár, T. Orehova, A. Toteva, V. Hristov, A. Benderev, A. Horvátha, L. Palcsu. 2019. Tracing groundwater recharge conditions based on environmental isotopes and noble gases, Lom depression, Bulgaria. Journal of Hydrology: Regional study, 24 (2019), Elsevier, 1-15, https://doi.org/10.1016/j.ejrh.2019.100611.

Yovchev, R., V. Ryzhova. 1962. Groundwaters of Northern Bulgaria. Glavnom upravlenii po geologii i okhrany nedr, Moscow, 222 p. (in Russian).

Постьпила: 16.11 .2021

Приета: 26.11.2021
Received: 16 November 2021

Accepted: 26 November 2021 